UDC 81.11'255.2:62 (045)

\title{
Tetiana Bondarenko
}

Senior lecturer

National Technical University of Ukraine

"Igor Sikorsky Kyiv Polytechnic Institute"

Kyiv, Ukraine

ORCID ID 0000-0001-7530-5501

tb.bondarenko@gmail.com

\section{Olena Miroshnychenko}

Fourth-year student

National Technical University of Ukraine

"Igor Sikorsky Kyiv Polytechnic Institute"

Kyiv, Ukraine

elorianelena@gmail.com

\section{CONVERSION PHENOMENON OF THE ENGLISH LANGUAGE: ITS DISTINCTIVE CHARACTERISTICS AND TRANSLATION INTO UKRAINIAN}

\begin{abstract}
This article focuses on the investigation of such linguistic phenomenon as conversion, namely its characteristic features in the system of English parts of speech and its translation into Ukrainian. Understanding the conversion forming mechanisms can significantly expand the wordstock of the English language. It is stated that there are several approaches to understanding this phenomenon, which are more likely to complement, but not contradict each other. It was determined that conversion refers to the main highly-productive types of word-formation. The article illustrates the main characteristics of conversion that distinguish this unique phenomenon among other types of word-formation and define the main reasons why it is so widespread in the English language. The research also presents analysis of this unique phenomenon in the system of English notional and functional parts of speech. In addition, the peculiarities of the translating the various semantic models of conversion from English into Ukrainian are properly investigated. For a better understanding, a great number of appropriate examples are given. At the same time, special attention is paid to the possible translation difficulties caused by striking differences in the English and Ukrainian languages. The investigation determines the ways of overcoming these difficulties. Moreover, the paper presents analysis of the conversion combinability with other types of word formation and interesting cases of converted phrases, sentences or their parts. The research encourages the idea of further investigation of conversion phenomenon. The results of this study can assist any translator in adequacy from English into Ukrainian.
\end{abstract}

Keywords: conversion; word-formation; notional and functional part of speech; external form; source word; derivative word; semantic model; equivalent; translation transformations.

\section{INTRODUCTION}

In fact, the English language is continuously changing nowadays. The main reason lies in the fact that the need in new words arises due to the development of different fields of human activities. Enrichment of the vocabulary has been achieved through various means among which the most effective and convenient one is a peculiar conversion phenomenon that can occur in both oral and written texts of various genres.

A large number of scholars have been engaged in the study of this phenomenon, such as Bauer (2005), Baltiro (2007), Ivanova (2014), Velasco (2009), Verba (2003), and others. However, despite a rather long history of this research, conversion is still one of the most controversial issues in modern linguistics. So far, there is no consensus even on the issue of the exact definition of this exceptional phenomenon. Moreover, the problem of translating different parts of speech from English into Ukrainian has not yet been fully investigated in translation studies.

The main objective of paper was to identify the essence of the conversion as a means of enriching the English vocabulary, to study the semantic models of words formed through conversion, as well as to determine the peculiarities of the translation of conversion from English into Ukrainian. 


\section{METHODS}

To achieve the goal, several methods were used, namely: bibliography method in processing of the works written by renowned scholars; analytical method to study the place of conversion in the word-forming system; deduction to identify the features of the English conversion based on the general characteristics of this phenomenon; descriptive method for representation of semantic models of conversion; comparative method to define differences between the Ukrainian and English languages; generalization method to formulate the definition of conversion based on the works of various linguists; transformation method in studying the methods of translation conversion.

\section{RESULTS AND DISCUSSION}

\subsection{Characteristics of the English conversion phenomenon}

Generally speaking, conversion (from Latin conversion - transformation, change) is a special type of transposition; a semantic, morphological and syntactic word-formation process of the word transition from one part of speech to another without any change in the external form of the original word, that is, without using typical affixes. Through conversion, one part of speech gets syntactic and grammatical features of another (Bauer, 2005).

It is considered that the term "conversion" was used in English for the first time in 1891 by Henry Sweet. However, the phenomenon itself appeared at the beginning of the Middle English period, as far back as the XIII century, as a result of the collapse of the inflexive system (Velasco, 2009).

The phenomenon of conversion is especially significant for the English language due to its analyticity. The number of words in English that is formed by conversion is steadily increasing.

The advantages of using conversion in English are:

- "speech saving". The maximum content is transmitted using limited linguistic resources. Neutral words are removed from the message and only important information remains. One word can convey the meaning of the whole sentence, for example, intellectual $\rightarrow$ intellectual (інтелектуальний $\rightarrow$ людина широких інтелектуальних інтересів); to put something into the pocket $\rightarrow$ to pocket something (покласти у кишеню); she hit him with a bat $\rightarrow$ she batted him (вона била його ціпком); he swept the floor with a broom $\rightarrow$ he broomed the floor (він підмітав підлогу);

- vivid demonstration of emotional state and character. Conversion is used as a stylistic device, for instance, the word to peacock is translated not just like «величатися», but more like “ходити павичем, задирати кирпу, губу копилити” (Dubravska, 2010; Ivanova, 2014).

\subsection{Semantic Models of Conversion in the English Language System}

Since there are no affixes when creating words by conversion, one important problem arises, namely the problem of determining the conversion direction. It is not always easy to say for sure what word is source, and what is derivative. To solve this problem, the etymology of the word should be checked first and foremost (Balteiro, 2007).

The phenomenon of conversion is inherent both in notional and functional parts of speech. Let us take a look at the basic semantic models of English conversion.

Noun $\rightarrow$ Verb model is the most productive conversion model in modern English. It includes the following pairs of words that denote:

1) an object name (instrument, artifact, tool) $\rightarrow$ to do a certain action with the help of this object:

- an instrument (tool) $\rightarrow$ to use this tool: a razor $\rightarrow$ to razor (бритва, лезо $\rightarrow$ голити);

- liquid $\rightarrow$ to use this liquid: water $\rightarrow$ to water (вода $\rightarrow$ мочити, змочувати, зволожувати, напувати, пити, поливати, розводити, пер. згладжувати);

- a body part $\rightarrow$ to perform an action with this body part: a finger $\rightarrow$ to finger (палець $\rightarrow$ торкатися, вказувати, перебирати пальцями, розм. брати хабарі);

- a vehicle $\rightarrow$ to travel on this vehicle: $a$ ship $\rightarrow$ to ship (корабель, судно $\rightarrow$ перевозити на кораблі, сідати на корабель); 
2) a name of the living being (human, animal) $\rightarrow$ to perform an act that characterizes this living being:

- a peculiarity of a person $\rightarrow$ to behave according to this peculiarity: a bootlick $\rightarrow$ to bootlick (підлабузник, підлесник $\rightarrow$ лестити, лизати п'яти);

- a job title $\rightarrow$ to carry out a certain job: a cook $\rightarrow$ to cook (кухар $\rightarrow$ куховарити, готувати);

- a family member $\rightarrow$ to behave in a typical for this family member way: a grandmother $\rightarrow$ to grandmother (бабуся $\rightarrow$ балувати, зніжувати, розпещувати);

- an animal name $\rightarrow$ to behave in a typical for this animal way, to do something with this animal: a parrot $\rightarrow$ to parrot (папуга $\rightarrow$ теревенити, безтямно повторювати);

3) an object of reality $\rightarrow$ to purchase, supply or dispose this object:

- an ingredient for preparing dishes $\rightarrow$ to cook with this ingredient: glair $\rightarrow$ to glair (яєчний білок $\rightarrow$ змазувати яєчним білком);

- a garment or an ornament $\rightarrow$ to dress or decorate something: a jewel $\rightarrow$ to jewel (коштовність, ювелірна річ $\rightarrow$ прикрашати коштовностями);

- an object $\rightarrow$ to get rid of it: weed $\rightarrow$ to weed (бур'ян $\rightarrow$ полоти, знищувати бур'ян);

4) a specific area $\rightarrow$ to move, place or stay in this area:

- a certain area name $\rightarrow$ to place something in this area: a basket $\rightarrow$ to basket (кошик, корзинка $\rightarrow$ складати, викидати у кошик);

- a certain area name $\rightarrow$ to place, stay, live, hold in a certain place: a tent $\rightarrow$ to tent (намет, шатро, тент $\rightarrow$ жити в наметах, стояти табором, ставити намет);

- a wrap $\rightarrow$ to enwrap in anything: paper $\rightarrow$ to paper (папір, шпалери $\rightarrow$ загортати у папір, обклеювати шпалерами);

5) a time period $\rightarrow$ to go through this period: vacation $\rightarrow$ to vacation (відпустка, канікули, відпочинок $\rightarrow$ брати (проводити) відпустку, відпочивати під час відпустки).

Noun $\rightarrow$ Adjective model:

1) a material name $\rightarrow$ made or composed of this material: leather $\rightarrow$ leather (шкіра $\rightarrow$ шкіряний);

2) a place name $\rightarrow$ typical for this place or located in this place: a bottom $\rightarrow$ bottom (дно, нижня частина $\rightarrow$ нижній, останній);

3) a person or creature $\rightarrow$ typical for this person or creature: a master $\rightarrow$ master (господар, пан $\rightarrow$ головний, старший);

4) a name of object, phenomenon or abstract concept $\rightarrow$ typical for this object, phenomenon or abstract concept: a model $\rightarrow$ model (модель, зразок $\rightarrow$ зразковий, взірцевий).

The conversion is inherent not only in common, but also in proper names, for example, Houdini (гіпнотизер та ілюзіоніст Гаррі Гудіні) $\rightarrow$ Houdini (майстерний) $\rightarrow$ to Houdini (втекти, обдуривши інших).

Verb $\rightarrow$ Noun model:

1) an action, process, change of position, sharp sound $\rightarrow$ a name of a short, one-time, instant action: to dive $\rightarrow$ a dive (пірнати; засовувати (запускати) руку (в кишеню) $\rightarrow$ стрибок у воду, пірнання, занурення);

2) an action $\rightarrow$ a process or state name:

- to express emotion $\rightarrow$ an emotion name: to anger $\rightarrow$ anger (сердити, гнівати, злити; викликати подразнення, запалення $\rightarrow$ гнів, лють, роздратування; подразнення, запалення);

- to perform a long-term action $\rightarrow$ a name of a quiet long-term occupation or psychological activity: to flow $\rightarrow$ a flow (текти, протікати $\rightarrow$ потік, течія);

- to make a long sound $\rightarrow$ a sound name: to purr $\rightarrow$ a purr (муркотати; гурчати (про мотор) $\rightarrow$ муркотання; рівна робота двигуна);

3) an action $\rightarrow$ a performer:

- to perform an action $\rightarrow$ a person for which this action is typical: to blab $\rightarrow$ a blab (балакати, теревенити $\rightarrow$ балакун, базіка); 
- to show a certain trait of character $\rightarrow$ a person who has this trait of character: to brag $\rightarrow$ a brag (хвалитися, вихвалятися $\rightarrow$ хвалько);

- to carry out a job $\rightarrow$ a job title: to cop $\rightarrow$ a cop (спіймати, застати (на місиі злочину) $\rightarrow$ поліцейський);

4) an action $\rightarrow$ a result of this action: to bargain $\rightarrow$ a bargain (торгуватися, вести переговори, домовлятися $\rightarrow$ торговельна угода, домовленість; вигідна покупка, задешево куплена річ);

5) an action $\rightarrow$ a scene of action: to stand $\rightarrow$ a stand (стояти $\rightarrow$ підставка, стенд, трибуна, стоянка).

Verb $\rightarrow$ Adjective model:

1) a stative verb $\rightarrow$ an adjective which characterizes this state: to degenerate $\rightarrow$ degenerate (погіршуватися, вироджуватися $\rightarrow$ погіршений, зіпсований, розбещений);

2) an action verb $\rightarrow$ an adjective which characterizes this action: to elect $\rightarrow$ elect (вирішувати, робити вибір, віддавати перевагу $\rightarrow$ обраний, відбірний);

3) a speech verb $\rightarrow$ an adjective which characterizes this speech: to express $\rightarrow$ express (висловлювати, виражати, відображати $\rightarrow$ спеціальний, терміновий, недвозначний, кур'єрський).

It is worth noting that the conversion of complex verbs (phrasal verbs) is an extremely productive phenomenon in modern spoken English. It is being implemented in two directions: Verb $\rightarrow$ Noun (to pull back $\rightarrow$ a pull-back (затримувати, утримувати, відступати $\rightarrow$ перешкода, завада, невигідне становище)); Verb $\rightarrow$ Adjective (to break away $\rightarrow$ breakaway (відривати, відійти, розійтися, вирватися $\rightarrow$ сепаратистський, той, що відколовся)). Sometimes the inversion of the adverbial component of the phrase derivative occurs: to turn down $\rightarrow$ a downturn (збавляти, зменшувати, відгортати, перевертати; розбирати $\rightarrow$ зниження, падіння, спад, скорочення).

The conversion is inherent not only in full verbs, but also in modal or auxiliary, for example: This is a must (Це нагальна потреба); They always have all-night dos there (У них постійно відбуваються нічні вечірки); I am tired of your don'ts (Мені набридли ваші заборони).

Adjective $\rightarrow$ Noun model:

1) a characteristic, quality $\rightarrow$ a group of people:

- a belonging to a certain nationality $\rightarrow$ a nationality name: Canadian $\rightarrow$ Canadian (канадський $\rightarrow$ канадець, канадка);

- characteristic of activity or movement $\rightarrow$ a supporter of this activity or movement: alcoholic $\rightarrow$ an alcoholic (алкогольний $\rightarrow$ алкоголік);

- moral, intellectual and physical characteristic $\rightarrow$ a person who has this characteristic: comic $\rightarrow$ a comic (комічний, гумористичний, смішний, потішний $\rightarrow$ актор-комік);

2) a characteristic or quality $\rightarrow$ an abstract or concrete concept:

- colour or shape: asteroid $\rightarrow$ asteroid (зіркоподібний $\rightarrow$ астероїд, морська зірка (тварина)); yellow $\rightarrow$ yellow (жовтий; боягузливий, підлий; бульварний (про пресу); ревнивий $\rightarrow$ жовтий колір, жовток; боязкість; бульварна газета);

- medical and chemical fields: antiseptic $\rightarrow$ an antiseptic (антисептичний; бездоганно чистий, нудно-упорядкований $\rightarrow$ антисептичний засіб, антисептик);

- grammatical notion: diminutive $\rightarrow$ diminutive (зменшувальний, крихітний $\rightarrow$ зменшувальний іменник, невелика річ, штучка, миршавий чоловічок).

\section{Adjective $\rightarrow$ Verb model:}

This model is not widespread because it is mostly used in combination with the words such as to be, to get, to make: (to be busy (бути зайнятим), shy $\rightarrow$ to shy (сором'язливий, нерішучий, полохливий, убогий $\rightarrow$ відступати, полохатися, вагатися, уникати).

Adjective $\rightarrow$ Adverb model: almighty $\rightarrow$ almighty (всемогутній; жахливий, страшенний $\rightarrow$ жахливо, надзвичайно; страшенно; дуже).

Adverb $\rightarrow$ Noun model: $f a r \rightarrow$ a far (далеко, давно, значно, набагато $\rightarrow$ далека відстань).

Adverb $\rightarrow$ Adjective model: daily $\rightarrow$ daily (щодня, завжди, постійно $\rightarrow$ щоденний, повсякденний). 
Numeral $\rightarrow$ Noun model: hundred $\rightarrow$ hundred (сто $\rightarrow$ сотня, нуль-нуль).

Numeral $\rightarrow$ Adjective / Pronoun model: one $\rightarrow$ one (один $\rightarrow$ хтось, якийсь).

Pronoun $\rightarrow$ Noun model: nothing $\rightarrow$ a nothing (ніщо, нічого $\rightarrow$ дрібниця, пусте місце, нуль, пустота, відсутність, небуття).

Pronoun $\rightarrow$ Verb model: you $\rightarrow$ to you (ви, вас, вам, вами, ти, тебе, тобі, тобою $\rightarrow$ звертатися на ви, викати).

Pronoun $\rightarrow$ Adjective model: that $\rightarrow$ that (те, ось що $\rightarrow$ цей, ця, це, той, та, те).

Pronoun $\rightarrow$ Adverb model: both $\rightarrow$ both (обидва, і той і інший $\rightarrow$ теж, також, однаково, одночасно).

Preposition $\rightarrow$ Noun model: inside $\rightarrow$ inside (усередині, у, в $\rightarrow$ внутрішня частина (бік), виворіт, нутро, внутрішній нападник).

Preposition $\rightarrow$ Verb model: out $\rightarrow$ to out (3, із, за $\rightarrow$ вигнати, виставити, гасити; усунути 3 поля; виходити).

Preposition $\rightarrow$ Adjective model: down $\rightarrow$ down (униз, по, за, через, крізь $\rightarrow$ спрямований униз; що йде від центру; спадний; нездоровий).

Preposition $\rightarrow$ Adverb model: across $\rightarrow$ across (крізь, через, упоперек $\rightarrow$ хрест-навхрест, по горизонталі, увімкнено паралельно).

Conjunction $\rightarrow$ Noun model: if $\rightarrow$ an if (якщо $\rightarrow$ припущення, вимога, умова).

Particle $\rightarrow$ Noun model: not $\rightarrow$ a not (не, ні $\rightarrow$ безрога вівця).

Particle $\rightarrow$ Adjective model: yet $\rightarrow$ yet (ще, все ще $\rightarrow$ теперішній, нинішній).

Interjection $\rightarrow$ Noun model: bravo $\rightarrow$ a bravo (Браво! $\rightarrow$ найманий убивця, бандит, головоріз).

Interjection $\rightarrow$ Verb: boo $\rightarrow$ to boo (Бу! $\rightarrow$ висловлювати невдоволення, проганяти) (Harmash, 2005).

Other parts of speech are often converted into exclamations; for example, Bless me (my soul)! (Боже!, Господи!, Їй-богу!); Dear me!, Oh dear! (Боже мій!); Bother! (Тьху ти!); Here someone! (Ей, хто-небудь! Ей, тут є хтось?); Well then? (Ну й що?!).

Nowadays, the combination of conversion with other means of word-formation such as affixation (to overwash $\rightarrow$ an overwash (перехлюпувати $\rightarrow$ повінь, затоплення)), word composition (a cat-nap $\rightarrow$ to cat-nap (дрімота $\rightarrow$ дрімати)), blending (brunch (вid breakfast + lunch) $\rightarrow$ to brunch (пізній сніданок, сніданок-обід $\rightarrow$ пізно снідати)), clipping (a copter $\rightarrow$ to copter (вертоліт $\rightarrow$ летіти вертольотом)), abbreviation or acronymy (SOS (вid save our souls) $\rightarrow$ to SOS (радіосигнал про біду (небезпеку) $\rightarrow$ подавати радіосигнал небезпеки), rif (вid reduction in forces) $\rightarrow$ to rif (звільнення $\rightarrow$ звільняти)) is a common tendency.

Many convertible units can be formed from phrases and sentences or their parts. For example, quick and dirty $\rightarrow$ a quick-and-dirty (зроблений нашвидкуруч $\rightarrow$ закусочна, забігайлівка); whosit $\rightarrow a$ whosit (хто там $\rightarrow$ як його там, цей самий); dog's ear $\rightarrow$ to dog's ear (загнутий ріжок сторінки $\rightarrow$ загинати ріжок сторінки) (Verba, 2003).

\subsection{Ways of Conversion Translation}

An interpreter should always analyze the context in which convertible units are used, without which the quality of translation cannot be achieved. For the most part, the converted words have the equivalent in the target language ( a brake $\rightarrow$ to brake (гальмо $\rightarrow$ гальмувати)) (Kvasylevych, \& Sasina, 2003). However, if such an analogue is still absent then correct translation transformations should be applied, among them are:

\section{1) lexical transformations:}

- transcoding:

1) transcription (a peak $\rightarrow$ to peak (пік $\rightarrow$ випинатися, стирчати; загострювати, акцентувати);

2) transliteration $($ a ping-pong $\rightarrow$ to ping-pong (пінг-понг, настільний теніс $\rightarrow$ розм. ганяти, перекидати кого-небудь, що-небудь туди-сюди; мед.; жарг. без потреби направляти (пацієнтів) до інших фахівців, на аналізи та процедури); 

рішучості));

3) mixed transcoding (a nerve $\rightarrow$ to nerve (нерв $\rightarrow$ надавати сили (мужності,

4) adaptive transcoding (a lamp $\rightarrow$ to lamp (лампа, ліхтар, світильник; розм. очі $\rightarrow$ освітлювати, сяяти; розм. витріщати очі));

- calque or loan translation (a hot key $\rightarrow$ to hotkey (гаряча клавіша $\rightarrow$ підключати до режиму «гарячі клавіші»);

2) lexico-semantic transformations:

- specification (how much did you give for that? (Скільки ти заплатив за це?) (to give $\rightarrow$ a give (давати, дарувати, виносити (рішення), заплатити $\rightarrow$ піддатливість, поступливість));

- generalization (the first factories were driven by water (перші фабрики працювали на воді) (to drive $\rightarrow a$ drive (приводити в рух, вести, керувати $\rightarrow$ привід; передача; механізм; їда));

- modulation (all the seats are booked (усі місця продані) (a book $\rightarrow$ to book (книга $\rightarrow$ заносити у книгу, замовляти заздалегідь (квиток)). It is possible to trace the connection of the process with the consequence: since all tickets were ordered in advance, there are no vacancies;

- emphasis (this man mouths platitudes (цей чоловік молов нісенітниці, але як урочисто) (a mouth $\rightarrow$ to mouth (рот, вуста; гирло (ріки) $\rightarrow$ говорити урочисто, хапати ротом; впадати (про ріку));

- neutralization (to nose into other people's affairs (втручатися в чужі справи) ( a nose $\rightarrow$ to nose (ніс $\rightarrow$ нюхати, обнюхувати, рознюхувати, тертися (тикатися) носом, совати свій ніс));

3) lexico-grammatical transformations:

- antonymic translation (negotiations collapsed (на переговорах мети досягнуто не було) (to collapse $\rightarrow$ a collapse (зазнати краху, невдачі, руйнуватись $\rightarrow$ обвал, руйнування, падіння, крах; банкрутство));

- descriptive translation:

1) explication: he is a crimp (Він агент, що вербус на військову службу обманом) (to crimp $\rightarrow$ a crimp (вербувати на військову службу обманом $\rightarrow$ агент, що вербує на військову службу обманом));

2) descriptive periphrase: (Both parties have milked the political situation (Обидві партії здобували вигоду з такої політичної ситуації) (milk $\rightarrow$ to milk (молоко $\rightarrow$ здобувати вигоду));

- functional substitution (make no stay! (не баріться!)) (to stay $\rightarrow$ a stay (залишатися, зупинятися, не здавати позицій $\rightarrow$ перебування, затримка, зволікання));

4) grammatical transformations:

- addition You don't like the heights, don't mountaineer! (Ти боїшся висоти, тому краще не лазити по горах) (a mountaineer $\rightarrow$ to mountaineer (горець, альпініст $\rightarrow$ лазити по горах, сходити на гори));

- omission (he was coptered out with a serious injury (його евакуювали iз серйозною травмою) (a copter $\rightarrow$ to copter (вертоліт $\rightarrow$ летіти на вертольоті, перевозити вертольотом));

- grammatical substitution (the change of the types of sentence (an English simple sentence can be turned into a Ukrainian complex sentence of the purpose: he came to the stable to saddle his horse (він прийшов до стані, щоб осідлати коня) (a saddle $\rightarrow$ to saddle (сідло $\rightarrow$ сідлати, осідлати));

- transposition (the motor was found to stop within 2 seconds (виявилося, що електромотор зупиняється протягом 2 секунд) (Karaban, 2002). 
The main complications that can occur while translating the phenomenon of conversion from English into Ukrainian are the difficulty of identifying a conversion, lack of equivalent or sense dissimilarity of derivative and source words.

\section{CONCLUSIONS AND SCOPE FOR FURTHER RESEARCH}

The research performed shows that conversion is one of the main highly-productive methods of word formation. It is a transition of a word from one part of speech to another without any change in the external form. The conversion provides the so-called "morphological freedom" and "speech saving". Moreover, language becomes more expressive and emotional thanks to conversion. The phenomenon of conversion is typical for the analytical English language. It was found that both notional and functional parts of speech can be formed by conversion. It has been proved that the translator should always analyze the context. Conversion is an interesting object for linguistic research and an important component of our modern life. Furthermore, materials of this article can come to assistance in future translation or teaching activities.

The results of the work will help to improve the practice of translating from English into Ukrainian.

\section{REFERENCES}

Balteiro, I. (2007). Contribution to the Study of Conversion in English. Münster, New York, Munich, and Berlin: Waxmann. [in English]

Bauer, L., \& Valera, S. (2005). Conversion or Zero-derivation: An Introduction. Approaches to Conversion. Zeroderivation. Münster, New York, Munich, and Berlin: Waxmann. [in English]

Collins dictionary. (n. d.). Retrieved from https://www.collinsdictionary.com/

Dubravska, D. (2010). Konversiya yak produktyvnyy sposib popovnennya slovnykovoho skladu anhliyskoyi movy. Linhvistyka XXI stolittya: novi doslidzhennya i perspektyvy [Conversion as a productive way of updating the vocabulary stores of the English language. Linguistics of the 21st century: new approaches and prospects]. Kyiv. [in Ukrainian]

Harmash, O. (2005). Systema slovotvoru anhliyskoyi movy ta innovatsiyni protsesy [The system of vocabulary of the English language and innovative processes]. Zaporizhzhya. [in Ukrainian]

Ivanova, M. (2014). Konversiya kak odin iz produktivnykh sposobov obogashcheniya slovarnogo sostava $v$ sovremennom angliyskom yazyke [Conversion as one of the productive ways of enriching vocabulary in modern English]. Moskva. [in Russian]

Karaban, V. (2002). Pereklad anhliyskoyi naukovoyi i tekhnichnoyi literatury: hramatychni trudnoshchi, leksychni, terminolohichni ta zhanrovo-stylistychni problem [Translation of English scientific and technical literature: grammatical difficulties, lexical, terminological and genre-stylistic problems]. Vinnytsya. [in Ukrainian]

Kvasylevych, D., \& Sasina, V. (2003). Praktykum z leksykolohiyi suchasnoyi anhliyskoyi movy [Workshop on the lexicology of the modern English language]. Vinnytsya. [in Ukrainian]

Velasco, D. G. (2009). Conversion in English and its implications for Functional Discourse Grammar. Lingua, 119(8), 1164-1185. [in English]

Velykyy akademichnyy slovnyk [Big academic dictionary]. (n. d.). Retrieved from https://dic.academic.ru/dic.nsf/enc3p/ [in Ukrainian]

Verba, L. (2003). Porivnyalna leksykolohiya anhliyskoyi ta ukrayinskoyi mov [Comparative lexicology of English and Ukrainian]. Vinnytsya [in Ukrainian]

Тетяна Бондаренко, Олена Мірошниченко. Конверсія як лінгвістичний феномен англійської мови: її основні характерні ознаки та переклад на українську мову. Статтю присвячено дослідженню такого мовного явища, як конверсія, а саме його характерним особливостям у системі англійських частин мови та його відтворенню в українському перекладі. Розуміння механізмів утворення конверсії дозволяє значно розширити словниковий запас англійської лексики. Встановлено, що існує декілька підходів до розуміння цього явища, які скоріш за все доповнюють, а не суперечать один одному. Було визначено, що конверсія відноситься до основних високопродуктивних способів словотвору. Стаття надає основні характеристики конверсії, які вирізняють це явище 3-поміж інших способів словотвору, та визначає основні причини її розповсюдженості в англійській мові. Також у роботі представлено аналіз цього унікального явища в системі англомовних самостійних та службових частин мови. Крім того, належним чином досліджено особливості перекладу різних семантичних моделей конверсії з англійської на українську мову. Для кращого розуміння суті статті наведено приклади. 
Приділено увагу можливим труднощам у перекладі, які виникають через значні відмінності англійської та української мов. Дослідження визначає шляхи подолання цих труднощів. У статті міститься аналіз взаємодії конверсії з іншими видами словотвору та випадки конвертованих фраз, речень та їх частин. Ця робота спонукає до подальшого дослідження явища конверсії. Результати цього дослідження стануть у нагоді перекладачу, який прагне досягти адекватності перекладу з англійської мови на українську.

Ключові слова: конверсія; словотвір; самостійні та службові частини мови; зовнішня форма; вихідне слово; похідне слово; семантична модель; еквівалент; перекладацькі трансформації.

Received: November 09, 2019 Accepted: November 24, 2019 